The Economic Journal, 115 (November), F324-F341. (C) Royal Economic Society 2005. Published by Blackwell Publishing, 9600 Garsington Road, Oxford OX4 2DQ, UK and 350 Main Street, Malden, MA 02148, USA.

\title{
THE IMPACT OF IMMIGRATION ON THE BRITISH LABOUR MARKET*
}

\author{
Christian Dustmann, Francesca Fabbri and Ian Preston
}

\begin{abstract}
Using data from the British Labour Force Survey this article provides an empirical investigation of the way immigration affects labour market outcomes of native born workers in Britain, set beside a theoretical discussion of the underlying economic mechanisms. We discuss problems arising in empirical estimation, and how to address them. We show that the overall skill distribution of immigrants is remarkably similar to that of the native born workforce. We find no strong evidence that immigration has overall effects on aggregate employment, participation, unemployment and wages but some differences according to education.
\end{abstract}

The possible negative effects of immigration on wages and employment outcomes of native workers is one of the core concerns in the public debate on immigration. Economic theory is well suited to help understand the possible consequences of immigration for receiving economies, and the theoretical aspects of the possible effects of immigration for the receiving economies' labour markets are well understood. That is not to say that predictions of theory are clear-cut, however. It is compatible with economic models that changes in the size or composition of the labour force resulting from immigration could harm the labour market prospects of some native workers; however, it is likewise compatible with theory that immigration even when changing the skill composition of the workforce has no effects on wages and employment of native workers, at least in the long run. Economic models predict that labour market effects of immigration depend most importantly on the structure of the receiving economy, as well as the skill mix of the immigrants, relative to the resident population.

Without empirical test, predictions of theoretical models remain at best wellreasoned speculation, and are not suited to guide policy. To quantify the effects of immigration on wages and employment of resident workers is therefore a main concern of economic analysis. A considerable number of papers address this issue, most of them for the US, with some studies for other European countries. ${ }^{1}$ Most papers find effects of immigration on wages and employment prospects of native workers which are either modest or absent. However, the general conclusion some

* We thank the British Home Office for financial support. Dustmann and Preston gratefully acknowledge the support of the Economic and Social Research Council (grant RES-000-23-0332). Fabbri also acknowledges financial support from the Munich Graduate School of Economics/Deutsche Forschungsgemeinschaft. We are grateful to Yasmin Dolatabadi for excellent research assistance. Important comments and advice were received from David Card, Wendy Carlin, Hidehiko Ichimura, Joanne Lindley, Costas Meghir, Jonathan Wadsworth, Carole Willis, and Frank Windmeijer. We thank the UK Data Archive at Essex for providing the data. All errors remain our own.

1 Studies for the US include Altonji and Card (1991), Borjas (1987; 2003), Butcher and Card (1991), Card $(1990 ; 2001)$ and this Feature, and LaLonde and Topel (1991). Studies for Europe include Pischke and Velling (1997) for Germany, Hunt (1992) for France, Carrington and de Lima (1996) for Portugal and Winter-Ebmer and Zweimüller (1996; 1999) for Austria, Friedberg (2001) and CohenGoldner and Paserman (2004) for Israel. See Dustmann and Glitz (2005) for an extensive survey of the literature. Other surveys include Borjas (1994; 1999) and Friedberg and Hunt (1995). 
draw from this evidence, that immigration has, at most, modest adverse effects on employment and wages, is not undisputed, and there is an ongoing debate about measurement and identification (Borjas, 2003).

While there are many empirical studies for the US, and some work for other European countries, no analysis exists for Britain. Given the difference in recent migration history, settlement, and type of immigrants to Britain, it would be wrong to infer from other studies the possible effects of immigration on the British labour market. One purpose of this article is to fill the gap in evidence for Britain. We commence by pointing out the circumstances under which we should expect immigration to have an effect on labour market outcomes of native workers, and the circumstances under which such effects may not be expected.

We then describe our empirical strategy. Our empirical model is directly derived from the theoretical work and allows therefore a straightforward interpretation of parameters within the framework set out by the theory. The dominant methodology in the literature, which we follow in this article also, is to seek to infer labour market effects from spatial correlations between local immigrant inflows and local changes in the labour market outcomes of natives. At the stage of empirical implementation, this methodology raises a number of important issues. Most of these relate to a clear isolation of the effect of immigration on native labour market outcomes from other associated phenomena, particularly in a context where immigrant inflows are themselves the outcome of economic decisions. We shall discuss the appropriate empirical strategies to solve these problems, and implement them as far as our data allows us to do so. For our analysis, we use data from the British Labour Force Survey (LFS).

We commence in the next Section with a brief account of the relevant economic theory that underlies the subsequent empirical work, and a discussion of the problems which occur on the empirical level. Next we describe the skill distribution of immigrants to Britain. We then explain the data sources we use and report results of our empirical analysis. Finally, we draw conclusions and suggest avenues for future work.

\section{Theory}

The theoretical analysis of the labour market effects of immigration sees effects as arising from the changes it introduces in supply of skills and consequent change in labour market equilibrium. Typically a distinction is drawn between skilled and unskilled labour. Immigration inflows affect the skill composition of the labour force if the skill composition of immigrants does not match the skill composition of natives. This change in skill composition leads to disequilibrium between supply of and cost-minimising demand for different labour types at existing wages and output levels. Restoration of equilibrium should be expected therefore to involve short-run changes in wages and employment levels of different skill types and may or may not require long-run changes as we allow the economy's output mix also to adjust. ${ }^{2}$

\footnotetext{
${ }^{2}$ A less common approach (Lalonde and Topel, 1991) treats immigrant and native labour as different labour types. In such a model the effect of immigration depends on substitutability between immigrant labour and native labour of different skill levels. The form of equations arising for estimation are nonetheless similar to those under the more common approach.
} 
The literature includes different approaches to theoretical modelling of these processes, implying different conclusions about the nature of long-run effects. The main differences in assumptions made involve

(i) differences in the number of goods produced and therefore in the flexibility of the economy to adapt through changes in mix of outputs, and

(ii) differences in openness of the goods sector to trade and therefore in the extent to which output prices are set locally or on world markets.

Models assuming limited flexibility of output mix or closedness to international trade tend to predict that immigration will have long-run wage and employment effects. Such features are typical of the underlying framework used as a motivation for empirical work in this literature; see, for example, the models of Borjas (1999) or Card (2001). ${ }^{3}$ On the other hand, models assuming a sufficiently high degree of flexibility in the mix of output produced in the traded goods sector predict an absence of long-run effects on labour market outcomes, at least to small scale immigration.

For illustration, consider first the effects of migration into an economy which produces, with a constant returns to scale technology, one output good only, sold at a price set on world markets, and using three factors of production: capital, skilled labour, and unskilled labour. ${ }^{4}$ Assume also that capital supply is perfectly elastic (which would be the case if the rate of return to capital is set on world markets) and labour supply of both skill groups is completely inelastic. Finally, assume that the skill composition of immigrants differs from that of native workers, and consider for illustration the case where all immigrants are low skilled. In this case, immigration will lead to a decrease in wages of low skilled native workers as the economy moves down the marginal product of labour curve for unskilled workers. If the change is more than marginal, then the immigrants are paid less than their average product and the owners of other factors enjoy a surplus from immigration. Since the return to capital is fixed this surplus accrues to skilled workers whose wages rise while those of native unskilled workers fall. There is therefore an aggregate gain but also redistribution with one labour type losing while the other gains. More generally, in such an economy, and if immigrants differ in their skill composition from natives, per capita income of the native population will increase as a consequence of migration, but the gains of migration are unequally distributed.

Supposing now that labour supply is actually somewhat elastic, immigration may also cause (voluntary) unemployment among those natives whose wages fall and who choose therefore to withdraw from supplying labour. Finally, notice that any wage effects are a consequence of immigration changing the skill structure of the workforce. No effects are to be expected if immigrants resemble resident workers in their skill composition. Below we will investigate this empirically for Britain.

\footnotetext{
${ }^{3}$ In this, these models share the features of standard models used in the broader literature on wage determination. See, for example, the papers of Katz and Murphy (1992), Murphy and Welch (1992) and Card and Lemieux (2001).

4 Technical details are given in the Appendix.
}

(C) Royal Economic Society 2005 
More generally, the lack of flexibility in an economy with a homogeneous traded goods sector means that there are insufficient degrees of freedom to accommodate changes in the skill mix through changes in the output mix. Wage changes are therefore not zero even in the long run.

Now contrast these conclusions with those appropriate to an economy with a heterogeneous traded goods sector in which output prices are fixed on world markets (and which, therefore, has relatively high flexibility in the output mix of traded goods). Assume again that labour supply is inelastic and that migration is unskilled. Holding outputs fixed, immigration would, as before, drive down wages of unskilled workers (and increase wages of skilled labour). This however drives up profits in a sector which uses unskilled labour more intensively and should therefore lead to a relative expansion of production in that sector, pushing up demand for unskilled labour and hence unskilled wages. Assuming the eventual equilibrium continues to involve positive production in all traded goods sectors, wages should return to the initial pre-immigration equilibrium. ${ }^{5}$ Rather than impacting on wages, long-run effects of immigration are felt in the output mix with production of the good using unskilled labour relatively intensively expanding according to predictions of the Rybczinski (1955) theorem.

Leamer and Levinsohn (1995) refer to this as the hypothesis of factor price insensitivity. ${ }^{6}$ This possible adjustment mechanism is sometimes mentioned in studies on the labour market impact of immigration; see, for example, Chiswick (1993), Borjas (1999), Card (2001), Friedberg and Hunt (1995) or Pischke and Velling (1997). Several recent contributions lay more stress on the need for models with multiple goods and openness to trade; see, for example, Kuhn and Wooton (1991), Scheve and Slaughter (2001), Hanson and Slaughter (1999; 2001), Gaston and Nelson $(2000 ; 2001)$. If labour supply is elastic, there may be both employment and wage effects in the short run, before output mix can fully adjust. Again, as in the one output case, no effects of migration on wages and employment are to be expected if the composition of migrant labour resembles that of the resident pre-migration population.

This exposition shows that a variety of possible outcomes are compatible with economic theory. Immigration may depress wages and employment of natives. However, it is by no means inconsistent with economic theory to think that long run responses to immigration may involve no effect, or that immigration increases wages of workers complementary to immigrant labour. As for the long-run effects, what matters is the openness of the economy to trade and the flexibility of the economy to adjust in respects other than wages and in particular through the mix of output produced. ${ }^{7}$

\footnotetext{
${ }^{5}$ In the extreme case, for sufficiently large scale immigration of unskilled labour, the economy may specialise in producing only the good that uses the immigrating factor more intensively. Factor price insensitivity will therefore prevail only as long as the factor endowments remain in the original 'cone of diversification'; see Bhagwati et al. (1998, chapter 28).

6 This result is related to the well known factor price equalisation result of trade theory - see, for example, Woodland (1982), Samuelson (1948) - although it is a weaker result.

7 Card (this Feature), drawing on Lewis (2003), reports that there is little evidence for the US that changes in industry structure are taking place. Lewis (2003) suggests that employers possibly adapt to the relative supply of different skill groups in their local market by introducing innovations that take advantage of more readily available factors, even in the absence of relative wage changes.
} 


\section{Empirical Implementation}

The dominant approach to estimation of such a model in the literature is that referred to by Borjas (1999) as the 'spatial correlations' approach. Effects of immigration are identified from the spatial correlation between immigrant labour inflows and changes in native or overall labour market outcomes (or between immigrant population shares and levels of these outcomes). Spatial units are intended to correspond to geographical labour markets.

The key problem in empirical analysis is to compare the economic outcomes of certain groups of the resident population in particular cells after immigration with the counterfactual outcomes that would be observed had migration not taken place. While the first measure is observable, the second is not, and needs to be constructed. Construction of this counterfactual involves always assumptions which are debatable.

The thought experiment in developing an empirical strategy based on local labour market variation in immigrant populations is that immigrants are randomly allocated across local labour markets, and that variation in economic outcomes is related to variation in immigrant densities. Problems arise with this strategy because levels of immigrant shares and levels of labour market outcomes may be spatially correlated because of common fixed influences, leading to a positive or negative statistical correlation between immigrant concentration and economic outcomes, even in the absence of any genuine effects of immigration. Elimination of common fixed influences could be achieved by using changes in economic outcomes and relating them to changes in immigrant concentrations. However, the direction of causality between immigrant inflows and labour market outcomes is not necessarily clear-cut. Immigrants may be attracted to those areas that are enjoying current economic success. This selective settlement would lead to an upwardly biased estimate of the effects of immigrants' concentration on labour market outcomes of natives.

A possible solution to this problem is to use measures of historic settlement patterns as instruments for immigrant inflows. The underlying justification is that immigrants will be attracted to settle where there are existing networks and the presence of individuals with the same cultural and linguistic background as themselves, inducing immigrants to settle in areas with already high immigrant concentrations. Pre-existing immigrant concentrations are unlikely to be correlated with current economic shocks if measured with a sufficient time lag, since existing concentrations are determined not by current economic conditions, but by historic settlement patterns of previous immigrants. ${ }^{8}$ The assumption that lagged values of immigrant stocks are correlated with employment changes only through their relation with immigrant inflows is an identifying assumption that is not testable. It could be problematic if local economic shocks were persistent and instruments were insufficiently lagged. The strength of correlation between lagged

\footnotetext{
${ }^{8}$ Work following this approach (Card, 2001) has been influenced by the findings of Bartel (1989) who argued that immigrants in the US tend to settle in areas where immigrant settlement is already strong.
}

(C) Royal Economic Society 2005 
concentrations and current inflows is observable in data and can therefore be assessed.

A further problem with studies that rely on relatively small sample sizes to compute immigrant concentrations and economic conditions on local level is measurement error. This is likely to be the case in an analysis that is based on a survey of relatively small sample size. The consequences of any measurement error is aggravated when using differenced or within groups estimation. This problem is addressed by instrumental variable estimation as long as the dependence on the regressor is linear, as it is in our case. The identification strategy we point out above should address measurement error as well.

Local labour markets are not closed economies and native workers are free to move out. If immigration does drive down local wages for certain skill groups then one would expect there to be pressure for native workers of that skill type to move elsewhere. This will tend to disperse the impact of immigration through the national economy and undermine the ability to identify the impact from looking at effects within localities, leading to downward biased estimates of the effect of immigration on, e.g., employment of native workers. This point has been stressed in numerous contributions. The US literature contains conflicting opinions on the seriousness of the problem. Borjas (2003) regards it as more serious than Card (2001, this issue).

For Britain, there is some evidence that mobility is, in general, low. Gregg et al. (2004) show that mobility amongst low skill/education people is limited, and often constrained by the housing market. Hatton and Tani (this Feature) use data from the International Passenger Survey and the National Health Service Registration Data to quantify the relationship between net inflows from abroad and the flows of residents within Britain. Their findings suggest a negative correlation between immigration to one region from abroad and in-migration from other British regions, which is significant for the South-East.

On the level of estimation, the problem is one of an omitted term in the estimated equation. The most attractive resolution to this problem is available if native outflows are observable and therefore amenable to incorporation directly into the estimation - a strategy we follow below. However such outflows are likely to be correlated with shocks to local economic conditions for the same reasons as immigrant flows, discussed above, creating a further simultaneity issue. These outflows therefore also need instrumenting and it is theoretically less clear what would serve as a suitable instrument. In practice we rely on lags.

\section{Immigrant and Native Skill Compositions}

In our discussion of the underlying theoretical model we emphasise that there are no effects of immigration to be expected on labour market outcomes of residents if immigration does not affect the skill composition of the resident labour force, and if capital supply is perfectly elastic. In the US, migration over recent decades has been predominantly unskilled (Borjas, 1999; Card and Lewis, 2005).

The situation for Britain is different, however, with immigrants being more similar in their education and skill distribution to the resident population. We

(C) Royal Economic Society 2005 
illustrate this by computing the percentage of native born workers, immigrants, and recent immigrants as of 2000 in three different education categories. Numbers are based on the LFS, which we describe in more detail below. We define recent immigrants as individuals who entered Britain over the last decade (between 1991 and 2000). Low education refers to no formal qualification; intermediate education to O-levels (or equivalent); and advanced education to A-levels or college/ university degrees.

We provide mean percentages of individuals in each of the three education groups in Table 1. While the percentage of native born workers in the highest education category is higher than the percentage of both immigrants and recent immigrants, the latter two groups are higher in the intermediate education category. For the unqualified, the percentages of immigrants and natives are fairly similar, while the percentage of recent immigrants is slightly lower.

These figures suggest that immigrants to Britain are fairly similar in their educational background to native born workers, at least on the national level.

An alternative measure for the distribution of immigrants across labour market skill groups is their observed occupational distribution. ${ }^{9}$ Again using data from the 2000 LFS, we have ranked 17 occupational groups by their mean earnings. We have then split the sample into three groups, which we refer to as 'skilled', 'semi-skilled' and 'unskilled'. The category 'skilled' includes the professions with the highest hourly wages: employers and managers, professional workers, employees with the armed forces. The category 'semiskilled' includes intermediate non-manual workers, junior non-manual workers, and foreman and supervisors. Finally, the category 'unskilled' includes farmers and farm workers, manual workers and personal service workers.

The numbers in the second panel of the Table show a remarkable similarity in the skill distribution across the three groups of natives, immigrants and recent immigrants. The similarity between groups is stronger than for the educational classification.

Table 1

Educational and Occupational Distribution, Immigrants and Natives

\begin{tabular}{lccc}
\hline \hline Education & Advanced education & Intermediate education & Low education \\
\hline Natives & 0.509 & 0.318 & 0.172 \\
Immigrants & 0.423 & 0.393 & 0.183 \\
Recent immigrants & 0.304 & 0.551 & 0.145 \\
Occupation & & & Unskilled \\
Natives & Skilled & Semiskilled & 0.356 \\
Immigrants & 0.246 & 0.397 & 0.326 \\
Recent immigrants & 0.313 & 0.361 & 0.324 \\
\hline \hline
\end{tabular}

Source: British Labour Force Survey 2000.

\footnotetext{
${ }^{9}$ In this paper, we choose to use education classification in our regressions. Information on occupation is only available consistently for individuals who are employed.
}

(C) Royal Economic Society 2005 
These results suggest that immigrants to Britain have a similar skill distribution to the native workforce. Based on these figures, we may conclude that at the national level there is no evidence that past or more recent immigration led to an increase of the ratio of unskilled to semiskilled or skilled workers. However, this does not imply that the skill distribution of immigrants across local labour markets is likewise similar to that of the native population; any conclusion that we should not expect labour market effects cannot be drawn on the basis of this evidence.

\section{Data and Descriptives}

The data set we use for our analysis is the British Labour Force Survey (LFS). The LFS is a household survey, conducted by the Office for National Statistics (ONS) on behalf of the Department for Education and Employment (DfEE). It provides a wide range of data on labour market statistics and related topics such as training, qualifications, income and disability. The LFS has been carried out in Britain since 1973. Between 1973 and 1983 it has been on a biennial basis, changing into an annul survey from 1983 onwards. The sample size is about 60,000 households in each survey, or around $0.5 \%$ of the population. From 1992 onwards, the survey changed to a rotating quarterly panel, with the same individuals being interviewed for five consecutive quarters. Each quarter about 59,000 households are interviewed with about 138,000 respondents. The quarterly LFS contains information on gross weekly wages and number of hours worked for the fifth quarter wave (1992-6) or the first and the fifth quarter (1997 onwards). The British LFS contains spatial information only at regional level, except for a brief interval between 1997 and 1999 when data was made available at county level. We therefore aggregate data at regional level, according to the region definition available in the LFS. ${ }^{10}$ For consistency across the years, we use 17 regions, namely, Tyne and Wear, Rest of Northern Region, South Yorkshire, West Yorkshire, Rest of Yorkshire and Humberside, East Midlands, East Anglia, Greater London, Rest of the South East, South West, West Midlands, Rest of West Midlands, Greater Manchester, Merseyside, Rest of North West, Wales and Scotland.

In our empirical analysis, we first focus on employment, defined as the proportion of the working age population employed. Below we will also present results for participation (the proportion of the working age population employed or looking for work), and unemployment (the proportion of those active in the labour market who are not employed). For these analyses we use data from the LFS from 1983 onwards. ${ }^{11}$ Wage information became available only in 1992 and we use data from 1992 until 2000 for the wage analysis. We use the log of (gross) hourly wages for the working population and for the skill subgroups. ${ }^{12}$

In Table 2 we present some summary statistics for the data we use for employment, unemployment and participation analysis. The summary statistics are based

10 The LFS provides information on the usual region of residence.

11 Information on education is available consistently only from 1983 onwards.

12 Hourly wages are derived dividing gross weekly wages by the number of hours worked.

(C) Royal Economic Society 2005 
Table 2

Descriptive Statistics, LFS 1983-2000

\begin{tabular}{lcc}
\hline \hline Variable & Mean & Standard deviation \\
\hline Employment & & \\
Total & 0.705 & 0.050 \\
Advanced education & 0.808 & 0.033 \\
Intermediate education & 0.712 & 0.043 \\
Unqualified & 0.558 & 0.075 \\
Unemployment & & \\
Total & 0.095 & 0.033 \\
Advanced education & 0.064 & 0.022 \\
Intermediate education & 0.100 & 0.036 \\
Unqualified & 0.147 & 0.044 \\
Participation & & \\
Total & 0.779 & 0.032 \\
Advanced education & 0.863 & 0.020 \\
Intermediate education & 0.791 & 0.026 \\
Unqualified & 0.652 & 0.068 \\
Wages (1992-2000) & & \\
Total & 2.076 & 0.128 \\
Advanced education & 2.237 & 0.122 \\
Intermediate education & 1.817 & 0.144 \\
Unqualified & 1.699 & 0.134 \\
Immigrant-native ratio & 0.072 & 0.079 \\
ln advanced/unqualified & 0.311 & 0.572 \\
ln intermediate/unqualified & 0.052 & 0.452 \\
Mean native age/100 & 0.377 & 0.010 \\
Mean immigrant age/100 & 0.386 & 0.018 \\
No. Obs. & & \\
\hline \hline & & 306 \\
\hline
\end{tabular}

on our aggregate data at regional level. The time interval is from 1983 to 2000. The analysis for wages considers a shorter period, and means are displayed in the second panel. In the third panel we report the means of the regressors used in our analysis, based on the sample used for employment analysis.

Employment is higher for the better educated, as well as for males, with an average employment rate of about $81 \%$. Unemployment and participation varies in a similar manner across education groups, with those who are better educated having a stronger labour market attachment as well as lower rates of unemployment. Wages are, as expected, considerably higher for those with an advanced education.

In the last panel we display means of variables we use as regressors in our analysis.

As was mentioned above, survey data may be characterised by small sample sizes when analysing specific groups in the population (like immigrants, in particular when breaking them down by education group, gender, or other demographic characteristics). This is due to the fact that immigrants represent a small fraction of the population (about $7.2 \%$ across regions and years, as shown in Table 2, and 9\% in LFS 2000), and that their geographical distribution in Britain appears to be very uneven (about $60 \%$ of immigrants of working age are concentrated in the Greater London and South East regions, against $29 \%$ of nonimmigrants).

(C) Royal Economic Society 2005 


\section{Estimation Strategy}

The model we derive in the Appendix suggests a relationship between labour market outcomes and the share of immigrants in the labour market. The estimation specification we adopt follows directly from (5), (6), (7) and (8) in the Appendix. Wages and labour supply measures are related to immigrant population share $\pi$ and to relative sizes of native skill groups, with additional controls for age composition of the population:

$$
O_{i t}=\alpha_{0}+\alpha_{1} \pi_{i t}+\alpha_{2} \ln \mathbf{n}_{i t}+\alpha_{3} \mathbf{a}_{i t}+\lambda_{t}^{O}+\mu_{i}^{O}+u_{i t}^{O}
$$

where $O_{i t}$ denotes the economic outcome under consideration (we consider employment, participation, and wages), $\pi_{i t}$ denotes the ratio of immigrant to native population, $\mathbf{n}_{i t}$ denotes a vector of native skill group populations and $\mathbf{a}_{i t}$ denotes a vector of average ages, all in the $i$ th region in the $t$ th period. Here $\lambda_{t}^{O}$ and $\mu_{i}^{O}$ are year and region effects and $u_{i t}^{O}$ is a disturbance term. Homogeneity is imposed on the native skill group effects by omitting one skill category and expressing the others as ratios with the size of the omitted skill group.

We report results using the OLS estimator, a difference estimator, and the IV estimator in differences. ${ }^{13}$ With OLS, the effect of immigration on economic outcomes is identified from the period-by-period cross sectional correlation between relative immigrant stocks and employment and wage levels. This offers a basic and straightforward point of comparison. Estimating the relationship in differences removes the influence of the fixed effects $\mu_{i}^{O}$. Identification of the effect is now from changes over time in the pattern of cross sectional variation. Although more robust than simple OLS, it still has problems with measurement error and simultaneity. Combining estimation in differences with use of instrumental variables addresses both the issues of measurement error and simultaneity. These final estimates are calculated by GMM imposing the moment restrictions that $\Delta u_{i t}^{O}$ are uncorrelated with the chosen instruments, which in each case are three and four-period lags of the endogenous regressors $\pi_{i t}$ and $\mathbf{n}_{i t}$. Weighting of restrictions and calculation of standard errors recognises the anticipated first order serial correlation in the differenced residuals.

In all estimated specifications we include a full set of year effects so that aggregate time series variation is completely absorbed. We also include controls for average age of immigrants and natives. These are taken as given in subsequent discussion. Size of native skill groups are also entered as controls in order to allow for the effect of native outflows. ${ }^{14}$

Tests are reported for first and second order serial correlation of residuals and for the overidentifying restrictions implied by the choice of instruments. For all IV estimates reported below there is clear evidence of first order serial correlation, as should be expected given differencing of the residuals but absence of second order serial correlation cannot be rejected at usual significance levels. The overidentifying restrictions are rejected in none of the specifications reported.

\footnotetext{
13 All estimates are calculated in GAUSS using DPD98 (Arellano and Bond, 1991, 1998).

${ }^{14}$ We impose the assumption that equiproportionate changes in all skill groups will have no effect. Coefficient estimates for these terms are generally not statistically significant.
}

(c) Royal Economic Society 2005 


\section{Results}

Table 3 presents a series of different estimates of effects on total native employment. OLS regression shows a slight positive relationship between employment and the immigrant-native population ratio. Removing persistent correlated effects by differencing switches the sign of the relationship, indicating that immigrants tend to be in areas with favourable employment conditions. Immigration is now associated with a decrease in employment. For the final and most robust of these estimates (columns $3)$, the hypothesis of no effect can not be rejected. An increase in immigration amounting to one per cent of the native population would lead, according to this result, to a decrease of 0.07 percentage points in the native employment rate but this estimated effect is far from significantly different from zero at conventional levels.

A Sargan test of the overidentifying restrictions is comfortably passed (as it is in all specifications which we estimate for the article) and the evidence of Table 4 suggests that instruments do predict the endogenous regressors well, particularly the changes in immigrant-native ratio. ${ }^{15}$

In Table 5 we report similar series of regressions for other economic outcomes. ${ }^{16}$ The results in the Table suggest that OLS results suggest an overly

Table 3

Effect of Immigration on Employment LFS 1983-2000

\begin{tabular}{|c|c|c|c|c|c|c|}
\hline \multirow[b]{2}{*}{ Variable } & \multicolumn{2}{|c|}{ OLS } & \multicolumn{2}{|c|}{ Differences } & \multicolumn{2}{|c|}{ IV } \\
\hline & Coeff & StdE & Coeff & StdE & Coeff & $S t d E$ \\
\hline Immigrant-native ratio & 0.088 & 0.040 & -0.154 & 0.083 & -0.070 & 0.096 \\
\hline ln advanced/unqualified & 0.090 & 0.012 & 0.048 & 0.014 & 0.034 & 0.068 \\
\hline ln intermediate/unqualified & 0.081 & 0.014 & 0.006 & 0.013 & 0.057 & 0.043 \\
\hline Mean native age $/ 100$ & 1.933 & 0.480 & 0.170 & 0.255 & 0.186 & 0.391 \\
\hline Mean immigrant age/100 & 0.198 & 0.101 & -0.007 & 0.056 & 0.003 & 0.062 \\
\hline$M_{1}$ & \multicolumn{2}{|c|}{$13.805 \mathrm{p}=0.000$} & \multicolumn{2}{|c|}{$-4.059 \quad \mathrm{p}=0.000$} & \multicolumn{2}{|c|}{$-3.256 \mathrm{p}=0.001$} \\
\hline$M_{2}$ & \multicolumn{2}{|c|}{$12.890 \mathrm{p}=0.000$} & \multicolumn{2}{|c|}{$-1.383 \quad \mathrm{p}=0.167$} & \multirow{2}{*}{\multicolumn{2}{|c|}{$\begin{array}{c}1.283 \mathrm{p}=0.200 \\
\chi_{5}^{2}=10.014 \\
\mathrm{p}=0.075\end{array}$}} \\
\hline$W_{1}$ & \multicolumn{2}{|c|}{$\chi_{5}^{2}=411.023$} & \multicolumn{2}{|c|}{$\chi_{5}^{2}=24.998$} & & \\
\hline$W_{2}$ & \multicolumn{2}{|c|}{$\begin{aligned} \mathrm{p} & =0.000 \\
\chi_{17}^{2} & =254.827\end{aligned}$} & \multicolumn{2}{|c|}{$\begin{aligned} \mathrm{p} & =0.000 \\
\chi_{17}^{2} & =426.004\end{aligned}$} & \multicolumn{2}{|c|}{$\chi_{14}^{2^{2}}=337.295$} \\
\hline$S$ & \multicolumn{2}{|c|}{$\mathrm{p}=0.000$} & \multicolumn{2}{|c|}{$\mathrm{p}=0.000$} & \multicolumn{2}{|c|}{$\begin{array}{c}p_{2}=0.000 \\
\chi_{3}=0.451 \\
p=0.930\end{array}$} \\
\hline Sample size & \multicolumn{2}{|c|}{306} & \multicolumn{2}{|c|}{289} & \multicolumn{2}{|c|}{238} \\
\hline
\end{tabular}

Notes:

All regressions include full set of time dummies. $M_{1}$ is a test for first-order serial correlation, asymptotically distributed as a standard normal

Instruments: 3 and 4-period lags of $\pi_{i t}$ and $n_{i t}$

$M_{2}$ is a test for second-order serial correlation, asymptotically distributed as a standard normal

$W_{1}$ is a Wald test for joint significance of the reported regressors

$W_{2}$ is a Wald test for joint significance of the unreported time dummies

$S$ is a $\chi^{2}$ test of the overidentifying restrictions implied by choice of instruments underlying IV estimates

${ }^{15}$ Wald tests for the irrelevance of excluded instruments reject strongly at any conventional significance level for immigrant native ratio and the intermediate/unqualified ratio and at the $10 \%$ level for the advanced/unqualified ratio.

${ }^{16}$ In this and subsequent Tables we suppress full reporting of coefficients on other regressors and associated test statistics. These results are available on request from the authors. 
Table 4

Significance of Excluded Instruments in First Stage Regression LFS $1983-2000$

\begin{tabular}{lr}
\hline \hline Variable & \multicolumn{1}{c}{ Wald test } \\
\hline Immigrant-native ratio & $\chi_{6}^{2}=254.946 \mathrm{p}=0.000$ \\
$\ln$ advanced/unqualified & $\chi_{6}^{2}=11.863 \mathrm{p}=0.065$ \\
$\ln$ intermediate/unqualified & $\chi_{6}^{2}=32.374 \mathrm{p}=0.000$ \\
\hline \hline
\end{tabular}

Table 5

Effect of Immigration on Unemployment, Participation and Wages LFS 1983-2000

\begin{tabular}{|c|c|c|c|c|c|c|}
\hline \multirow[b]{2}{*}{ Variable } & \multicolumn{2}{|c|}{ OLS } & \multicolumn{2}{|c|}{ Differences } & \multicolumn{2}{|c|}{ IV } \\
\hline & Coeff & $S t d E$ & Coeff & StdE & Coeff & StdE \\
\hline Unemployment & -0.050 & 0.026 & 0.106 & 0.067 & 0.066 & 0.103 \\
\hline Participation & 0.057 & 0.028 & -0.082 & 0.071 & -0.035 & 0.088 \\
\hline Wages & 0.802 & 0.107 & 0.198 & 0.677 & 0.909 & 0.583 \\
\hline
\end{tabular}

Notes: Reported coefficients are for immigrant-native ratio. All regressions include full set of time dummies and controls for native skill group sizes and mean native and immigrant ages.

Instruments: 3 and 4 period lags of $\pi_{i t}$ and $n_{i t}$ For both IV results, the Sargan test of overidentifying restrictions fails to reject at $5 \%$ significance level in all specifications.

optimistic effect of immigration on the various economic outcomes - similar to results on employment. Again, persistence in economic conditions and immigrant concentrations explains these results. Eliminating this factor by estimating differences changes the sign of the relationship for both unemployment and participation, suggesting a positive association between immigration and unemployment and a negative association between immigration and participation. Coefficients are however not significantly different from zero. The relationship between wages and immigration remains positive.

The last column presents IV results. Point estimates decrease slightly and suggest that there is no strong evidence of impact on native unemployment or participation rates. Estimated wage effects are positive and substantial but the preferred IV estimates are again statistically insignificant. The results for wages should be treated with particular caution given the smaller range of years available for estimation.

\subsection{Distinguishing Between Different Education and Demographic Groups}

Table 6 reports separate results for workers in different education groups. Educational classification follows the definitions in Section 3. We only report estimates obtained from the IV estimator. For the employment, unemployment and participation regressions the dependent variable is defined as the numbers employed, unemployed and participating in the group concerned divided by total relevant

(C) Royal Economic Society 2005 
Table 6

Effect of Immigration by Education Group LFS 1983-2000

\begin{tabular}{llccccr}
\hline \hline & \multicolumn{5}{c}{ IV, Differences } \\
\cline { 2 - 7 } & \multicolumn{2}{c}{ Advanced } & \multicolumn{2}{c}{ Intermediate } & \multicolumn{2}{c}{ Unqualified } \\
\hline Variable & Coeff & StdE & Coeff & StdE & Coeff & StdE \\
Employment & 0.111 & 0.068 & -0.179 & 0.052 & -0.028 & 0.058 \\
Unemployment & 0.001 & 0.044 & 0.098 & 0.043 & -0.034 & 0.075 \\
Participation & 0.108 & 0.061 & -0.108 & 0.050 & -0.063 & 0.073 \\
Wages & 0.930 & 0.990 & 0.153 & 1.044 & 3.798 & 3.397 \\
\hline \hline
\end{tabular}

Notes: As for Table 5 .

native population. This has the interpretive advantage that the estimated coefficients (roughly) ${ }^{17}$ add up to the total effects (because of the common denominator) and therefore provide a breakdown of the total effect across education groups.

Estimated employment, unemployment and participation effects are individually statistically significant only for the intermediate education group - those with O-levels but no higher - for whom the effects consistently suggest a depressive effect on labour market activity and probability of working. Nonetheless this seems to be offset by increasing employment of the more educationally qualified - with the net effect being not significantly different from zero, as our aggregate results above have shown. For the unqualified effects are very weakly determined. Albeit that the effects here are typically not very precisely estimated, the evidence does fit with the fact that immigration appears to have expanded the intermediate education group in particular, as discussed in Section 3.

Similar regressions for wages show consistently positive but weakly determined effects, which again are least beneficial for the group with intermediate education. The small sample sizes on immigrants when distinguishing between populations with different characteristics suggest to interpret these results with caution.

In none of these specifications have the dynamics of the relationship been explored. We have been unable to find statistically reliable and well determined estimates of dynamic specifications and have therefore refrained from commenting on differences between short-run and long-run effects. We note however that considerations of economic theory suggest that long run adjustments to immigration are likely to lower the magnitude of effects and that the estimates here are likely to overestimate long-run responses.

\footnotetext{
17 Adding up is not exact because not all individuals in the LFS can be classified educationally but the discrepancies are small.
}

(C) Royal Economic Society 2005 


\section{Discussion and Conclusion}

This article provides a first analysis of the way immigration may affect labour market outcomes of native workers in Britain. We commence by reviewing and discussing the theoretical background. These considerations suggest that the effects immigration may have on the labour market outcomes of resident workers are by no means clear-cut: they depend most importantly on the way immigration affects the skill mix of the resident population, as well as the way the economy may adjust to changes in the skill mix. These considerations emphasise the risk in drawing conclusions for Britain from analysis of other countries' labour markets as both the composition of immigrant inflows as well as the adjustment mechanisms differ across countries. Moreover, theoretical considerations like those discussed in this article assume that the labour market is in equilibrium before and after immigration. However, migrations are often a consequence of disequilibrium situations - for instance the large migrations to Europe in the period between 1955 and 1973 were a response to an excess demand for labour; see Dustmann (1996) for details. This is likely to change the results of any empirical investigation - again, to an extent crucially depending on the type and magnitude of initial disequilibrium.

The importance of careful consideration of possible differences in migration types is illustrated in our article. Unlike the US or some continental European countries, immigration to Britain is not concentrated at the lower end of the skill distribution but immigrants (recent immigrants as well as the existing immigrant population) resemble quite closely the skill composition of the resident native workforce. This is interesting and has in our view not yet received sufficient attention in the debate about possible effects of immigration.

Empirical analysis of the effects of immigration on outcomes of native born workers faces a number of challenges, as we do not directly observe outcomes for native born workers that would have occurred in the absence of immigration. The approach we follow in this article is to use variation in immigration to different spatial areas and to instrument this by variation in historical settlement patterns.

Our analysis focuses on a range of labour market outcomes: employment, unemployment, participation and wages. The main result is that we find little evidence of overall adverse effects of immigration on native outcomes. If there is evidence of negative effects on employment in any group, then it is for those with intermediate education levels, but this is offset in the aggregate by positive effects on employment among the better qualified. Estimated wage effects, based on a shorter run of data, are if anything positive but statistically poorly determined.

We have drawn attention to many weaknesses in the available data and conceptual problems in the empirical analysis all of which should urge caution before drawing strong conclusions. We consider our investigation as a first step in analysing this important issue for Britain. We have repeatedly hinted at the relatively poor quality of data available for research of this type in Britain. The possibility of accessing a finer regional breakdown in the LFS, might for instance be one step towards an improved analysis. 


\section{Appendix: Immigration and the Labour Market}

\section{A1. Labour Market Equilibrium}

We outline here a simple model of the effect of immigration on the labour market. Let $N$ denote total native population and $M$ total immigrant population. Suppose there are two labour types, skilled and unskilled, earning wages $w_{S}$ and $w_{U}$. Numbers of workers of the two types are

$$
x_{i}=N_{i}+M_{i}, \quad i \in I \equiv\{S, U\}
$$

where $N_{i}$ is total native workforce of the type and $M_{i}$ is total immigrant workforce of the type. Hence, assuming ratio of immigrant to native population, $\pi=M / N$, is small,

$$
\mathrm{d} \ln x_{i} \simeq \mathrm{d} \ln N_{i}+\beta_{i} \mathrm{~d} \pi \quad i \in I
$$

where $\beta_{i}=\left(M_{i} N / N_{i} M\right)$ is relative skill share of immigrants. Supply of labour is then $x_{i} l_{i}\left(w_{i}, p\right), \quad i \in I$, where $x_{i}$ is number of workers of the $i$ th type and $l_{i}\left(w_{i}, p\right)$ is a labour supply function. Capital is assumed elastically supplied at a return to capital, $r$, which is fixed on world markets.

We consider two cases differing in the number of goods produced by the economy. Either the economy produces one good in quantity $y_{0}$ or two goods in quantities $y_{0}$ and $y_{1}$. We denote the set of goods by $J$ which therefore equals $\{0\}$ or $\{0,1\}$. These goods are assumed traded and the economy small so that their prices $p_{0}$ and $p_{1}$ are therefore set on world markets. $^{18}$

Assuming constant returns to scale and excluding the possibility of joint production, we write the unit cost function for the $j$ th output as $c^{j}\left(w_{S}, w_{U}, r\right), \quad j \in J$. Letting $c_{i}^{j}\left(w_{S}, w_{U}, r\right)$ denote the derivative $\partial c^{j} / \partial w_{i}$, demand for the $i$ th type of labour is therefore $\sum_{j \in J} y_{j} c_{i}^{j}$ by Shephard's lemma.

Wages and outputs are determined by two equilibrium conditions. Firstly, labour market equilibrium requires equality of demand and supply of labour ie

$$
\sum_{j \in J} y_{j} c_{i}^{j}\left(w_{S}, w_{U}, r\right)-x_{i} l_{i}\left(w_{i}, p\right)=0 \quad i \in I
$$

and secondly, firms earn zero profits and therefore

$$
\ln c^{j}\left(w_{S}, w_{U}, r\right)-\ln p_{j}=0 \quad j \in J .
$$

\section{A2. One Output Good}

Considering first the case with only one output, we have

$$
\begin{aligned}
\mathrm{d} \ln y_{0}+\left(\varepsilon_{S S}^{0}-\eta_{S}\right) \mathrm{d} \ln w_{S}+\varepsilon_{S U}^{0} \mathrm{~d} \ln w_{U} & =\mathrm{d} \ln x_{S}=\mathrm{d} \ln N_{S}+\beta_{S} \mathrm{~d} \pi \\
\mathrm{d} \ln y_{0}+\varepsilon_{U S}^{0} \mathrm{~d} \ln w_{S}+\left(\varepsilon_{U U}^{0}-\eta_{U}\right) \mathrm{d} \ln w_{U} & =\mathrm{d} \ln x_{U}=\mathrm{d} \ln N_{U}+\beta_{U} \mathrm{~d} \pi \\
\theta_{S}^{0} \mathrm{~d} \ln w_{S}+\theta_{U}^{0} \mathrm{~d} \ln w_{U} & =0
\end{aligned}
$$

where $\varepsilon_{i j}^{0}=\partial \ln c_{i}^{0} / \partial \ln w_{j}$ denotes a labour demand elasticity, $\theta_{i}^{0}=\partial \ln c^{0} / \partial \ln w_{i}$ denotes a factor share and $\eta_{i}=\partial \ln l^{i} / \partial \ln w_{i}$ denotes a labour supply elasticity.

Hence, by substitution,

\footnotetext{
${ }^{18}$ In the context of regional labour markets we need only think of $p$ being set in inter-regional trade.
} 


$$
\begin{gathered}
\mathrm{d} \ln w_{U}=\frac{\mathrm{d} \ln \left(N_{S} / N_{U}\right)+\left(\beta_{U}-\beta_{S}\right) \mathrm{d} \pi}{\left(\varepsilon_{U U}^{0}-\eta_{U}\right)-\left(\varepsilon_{S U}^{0}+\frac{\theta_{U}^{0}}{\theta_{S}^{0}} \varepsilon_{U S}^{0}\right)+\left(\varepsilon_{S S}^{0}-\eta_{S}\right) \frac{\theta_{U}^{0}}{\theta_{S}^{0}}} \\
\mathrm{~d} \ln w_{S}=-\frac{\theta_{U}^{0}}{\theta_{S}^{0}} d \ln w_{U} .
\end{gathered}
$$

Negativity of the denominator in (4) follows from concavity of the cost function ${ }^{19}$ if we assume also that $\eta_{S}, \eta_{U}<0$. Unskilled immigration therefore depresses unskilled wages and raises skilled wages. Effects on overall mean native wages depend on the proportions of natives in the two groups. Note also that it is change in relative size of native skill groups that matters to wages (given the assumptions of perfectly elastic capital supply and constant returns to scale).

Effects on employment then follow from

$$
\begin{aligned}
& \mathrm{d} \ln l_{U}=\eta_{U} \mathrm{~d} \ln w_{U} \\
& \mathrm{~d} \ln l_{S}=\eta_{S} \mathrm{~d} \ln w_{S}
\end{aligned}
$$

and clearly depend on the magnitude of labour supply elasticities. If $\eta_{U}$ and $\eta_{S}$ are zero then there are no equilibrium employment effects even if wages are affected. In particular there need be no equilibrium effect on proportion of the native population employed unless labour supply responds to wage changes at the extensive margin.

\section{A3. Two Output Goods}

Take now the case with two types of output. Considering only (3), we have

$$
\begin{aligned}
& \theta_{S}^{0} \mathrm{~d} \ln w_{S}+\theta_{S}^{0} \mathrm{~d} \ln w_{U}=0 \\
& \theta_{S}^{1} \mathrm{~d} \ln w_{S}+\theta_{U}^{1} \mathrm{~d} \ln w_{U}=0
\end{aligned}
$$

from which it follows immediately that $\mathrm{d} \ln w_{U} / \mathrm{d} \pi=\mathrm{d} \ln w_{U} / \mathrm{d} \pi=0$. This result, essentially an implication of the factor price equalisation theorem (Samuelson 1948), is what Leamer and Levinsohn (1995) call factor price insensitivity. Wages are determined solely by prices through the zero profit condition. Effects on employment are also zero in long run equilibrium.

Rather than impacting on wages, long-run effects of immigration are felt in the output mix. These responses can also be deduced and follow from (3) given unchanged factor prices:

$$
\begin{gathered}
\rho_{S}^{0} \mathrm{~d} \ln y_{0}+\left(1-\rho_{S}^{0}\right) \mathrm{d} \ln y_{1}=\mathrm{d} \ln N_{S}+\beta_{S} \mathrm{~d} \pi \\
\rho_{U}^{0} \mathrm{~d} \ln y_{0}+\left(1-\rho_{U}^{0}\right) \mathrm{d} \ln y_{1}=\mathrm{d} \ln N_{U}+\beta_{U} \mathrm{~d} \pi
\end{gathered}
$$

where $\rho_{i}^{j}=y_{j} c_{i}^{j} / \sum_{k \in J} y_{k} c_{i}^{k}$ denotes a sectoral share in a factor market. Therefore

19 Note that

$$
\varepsilon_{U U}^{0}-\left(\varepsilon_{S U}^{0}+\frac{\theta_{U}^{0}}{\theta_{S}^{0}} \varepsilon_{U S}^{0}\right)+\varepsilon_{S S}^{0} \frac{\theta_{U}^{0}}{\theta_{S}^{0}}=\frac{w_{U}}{c_{U}^{0}}\left[c_{U U}^{0}-2 \frac{c_{U}^{0}}{c_{S}^{0}} c_{S U}^{0}+\left(\frac{c_{U}^{0}}{c_{S}^{0}}\right)^{2} c_{S S}^{0}\right]
$$

which is a positive multiple of a quadratic form in the second derivatives of the cost function and therefore negative.

(C) Royal Economic Society 2005 


$$
\mathrm{d} \ln \left(y_{0} / y_{1}\right)=\frac{\mathrm{d} \ln \left(N_{S} / N_{U}\right)+\left(\beta_{S}-\beta_{U}\right) \mathrm{d} \pi}{\rho_{S}^{0}-\rho_{U}^{0}}
$$

and unskilled immigration leads to a relative expansion of the sector using unskilled labour relatively intensively, in line with the Rybczinski (1955) theorem.

For fixed levels of output, labour market equilibrium would imply wage changes. However these would lead to positive profits being earned in sectors using intensively labour types which become cheaper. Output in such sectors would be expected to expand driving wages back up and long-run equilibrium will not be restored until wages are driven back to their initial levels.

The nature of the solution in general depends upon a comparison between the numbers of goods produced and of labour types. This observation can be generalised beyond the case of only two labour types and can also be extended to allow for non-traded goods. ${ }^{20}$ What is at issue is the ability of the economy to respond to immigration through flexibility in its output mix. A smaller number of traded goods mean that there are insufficient degrees of freedom to accommodate changes in the skill mix through changes in the output mix and wage changes are therefore non-zero even in the long run. However with sufficient number of traded goods there is no need for immigration to induce factor price changes.

\section{University College London \\ University of Munich \\ University College London}

\section{References}

Altonji, J.G. and Card, D. (1991). 'The effects of immigration on the labor market outcomes of lessskilled natives', in (J.M. Abowd and R. B. Freeman, eds.), Immigration, Trade and Labor, pp. 201-34, Chicago: University of Chicago Press.

Arellano, M. and Bond, S.R. (1991). 'Some tests of specification for panel data: Monte Carlo evidence and an application to employment equations', Review of Economic Studies, vol. 58, pp. 277-97.

Arellano, M. and Bond, S.R. (1998). 'Dynamic panel data estimation using DPD98 for Gauss: a guide for users', mimeo, London.

Bhagwati, J.N., Panagariya A. and Srinivasan, T. N. (1998). Lectures on International Trade. 2nd edition, Cambridge MA: MIT Press.

Bartel, A.P. (1989). 'Where do the new U.S. immigrants live?', Journal of Labor Economics, vol. 7, pp. 37191.

Borjas, G.J. (1987). 'Immigrants, minorities, and labor market competition', Industrial and Labor Relations Review, vol. 40(3), (April), pp. 382-92.

Borjas, G.J. (1994). 'The economics of immigration', Journal of Economic Literature, vol. 32(4), pp. 1667717.

Borjas, G.J (1999). 'The economic analysis of immigration'. Chapter 28, Handbook of Labor Economics, vol. 3, pp. 1697-760, place: publisher.

Borjas, G.J. (2003). 'The labor demand curve is downward sloping: reexamining the impact of immigration on the labor market', Quarterly Journal of Economics, vol. 118, pp. 1335-74.

Butcher, K. and Card, D. (1991). 'Immigration and wages: evidence from the 1980s', American Economic Review, vol. 81(2), pp. 292-6.

Card, D. (1990). 'The impact of the Mariel Boatlift on the Miami labor market', Industrial and Labor Relations Review, vol. 43, pp. 245-57.

Card, D. (2001). 'Immigrant inflows, native outflows, and the local labor market impacts of higher immigration', Journal of Labor Economics, vol. 19(1), pp. 22-63.

Card, D. and Lemieux, T. (2001). 'Can falling supply explain the rising return to college for younger men? A cohort-based analysis', Quarterly Journal of Economics, vol. 116(2), pp. 705-46.

Card, D. and Lewis, E.G. (2005). 'The diffusion of Mexican immigrants during the 1990s: explanations and impacts', mimeo, University of California at Berkeley.

20 The relevant algebra can be drawn from trade theory models - see Ethier (1984), Woodland (1982).

(C) Royal Economic Society 2005 
Carrington, W. J. and de Lima, P.J.F. (1996). 'The impact of 1970s repatriates from Africa on the Portuguese labor market', Industrial and Labor Relations Review, vol. 49(2), pp. 330-47.

Chiswick, B.R. (1978). 'The effect of Americanization on the earnings of foreign-born men', Journal of Political Economy, vol. 86, pp. 897-921.

Chiswick, B.R. (1993). 'Review of immigration and and the work force: economic consequences for the United States and source areas', Journal of Economic Literature, vol. 31, pp. 910-1.

Cohen-Goldner, S. and Paserman, D. (2004). 'The dynamic impact of immigration on natives' labor market outcomes: evidence from Israel', IZA working paper 1315.

Dustmann, C. (1996). 'Return migration: the European experience', Economic Policy, vol. 22, pp. $215-50$.

Dustmann, C. and Glitz, A. (2005). 'Immigration, jobs and wages: theory, evidence and opinion', CEPRCReAM publication, London.

Ethier, W. J. (1984) 'Higher dimensional issues in trade theory', in (R. W. Jones and P. B. Kenen, eds.), Handbook of International Economics, vol. 1, pp. 131-84, Amsterdam: North Holland Press.

Friedberg, R.M. (2001). 'The impact of mass migration on the Israeli labor market', Quarterly Journal of Economics, vol. 116(4), pp. 1373-408.

Friedberg, R.M. and Hunt, J. (1995) 'The impact of immigration on host country wages, employment and growth', Journal of Economic Perspectives, vol. 9, pp. 23-44.

Gaston, N. and Nelson, D. (2000). 'Immigration and labour-market outcomes in the United States: a political-economy puzzle', Oxford Review of Economic Policy, vol. 16(3), pp. 104-14.

Gaston, N. and Nelson, D. (2001). 'The employment and wage effects of immigration: trade and labour economics perspectives', University of Nottingham, Leverhulme Centre for Research on Globalisation and Economic Policy Research Paper 2001/28.

Gregg, P., Machin, S. and Manning, A. (2004), 'Mobility and joblessness', in (R. Blundell, D. Card, R. Freeman, eds.), Seeking a Premier League Economy, pp. 371-410, Chicago: University of Chicago Press.

Hanson, G.H. and Slaughter, M.J. (1999). 'The Rybczinski Theorem, factor-price equalization, and immigration: evidence from U.S. states', National Bureau of Economic Research Working Paper No. 7074.

Hanson, G.H. and Slaughter, M.J. (2001). 'Labor market adjustment in open economies: evidence from U.S. states', Journal of International Economics, forthcoming.

Hunt, J. (1992). 'The impact of the 1962 repatriates from Algeria on the French labor market', Industrial and Labor Relations Review, vol. 45(3), pp. 556-72.

Katz, L.F. and Murphy, K.M. (1992). 'Changes in relative wages, 1963-1987: supply and demand factors', Quarterly Journal of Economics, vol. 107, pp. 35-78.

Kuhn, P. and Wooton, I. (1991). 'Immigration, international trade and the wages of native workers', in (J.M. Abowd and R. B. Freeman, eds.), Immigration, Trade and Labor, Chicago: University of Chicago Press.

Lalonde, R.J. and Topel, R.H. (1991). 'Labor market adjustments to increased immigration', in (J.M. Abowd and R. B. Freeman, eds.), Immigration, Trade and Labor, Chicago: University of Chicago Press.

Leamer, E. E. and Levinsohn, J. (1995). 'International trade theory: the evidence', in (G.M. Grossman and K. Rogoff, eds.), Handbook of International Economics, vol. 3, pp. 1339-94, Amsterdam: North Holland Press.

Lewis, E.G. (2003). 'Local open economics within the U.S. how do industries respond to immigration?', Federal Reserve Bank of Philadelphia Working Paper.

Murphy, K.M. and Welch, F. (1992). 'The structure of wages', Quarterly Journal of Economics, vol. 107(1), pp. 285-326.

Pischke, J. and Velling, J. (1997). 'Employment effects of immigration to Germany: an analysis based on local labor markets', Review of Economics and Statistics, vol. 79(4), pp. 594-604.

Rybczinski, T. M. (1955). 'Factor endowments and relative commodity prices', Economica, vol. 22, pp. 336-41.

Samuelson, P. A. (1948) 'International trade and the equalization of factor prices', Economic JournaL, vol. 48 , pp. $163-84$.

Scheve, K.F. and Slaughter, M.J. (2001). 'Labor market competition and individual preferences over migration policy', Review of Economics and Statistics, vol. 83(1), pp. 133-45.

Winter-Ebmer, R. and Zweimüller, J. (1996) 'Immigration and the earnings of young native workers', Oxford Economics Papers, vol. 48, pp. 473-91.

Winter-Ebmer, R. and Zweimüller, J. (1999) 'Do immigrants displace young native workers: the Austrian experience', Journal of Population Economics, vol. 12(2), pp. 327-40.

Woodland, A. (1982). International Trade and Resource Allocation, Amsterdam: North-Holland. 